\title{
Cultivation and Trafficking of Narcotics as Organized Crime in Albania: The Methods and Tools Used in Preventing this Crime: Why are these Crimes Still Matters of Great Concern?
}

\author{
MSc. Anton Bardhaj \\ National Bar Association, Albania; Email: bardhajanton@gmail.com \\ Gledina Mecka, PhD Candidate
}

National Bar Association, Albania; Email: jurist.gledina@gmail.com

\author{
Doi:10.5901/ajis.2015.v4n3s1p379
}

\section{Abstract}

\begin{abstract}
Organized crime in Albania, especially in cultivating and trafficking narcotics, is still a matter of concern. Matter of concern is also money laundry derived from narcotics trafficking. Despite the fact that the Albanian Government has undertaken several measures (legislative measures, strategies and action plans), we are still facing with this issue. Based on statistics, it is shown that the tense economic and politic situation in a country contributes to increasing the level of crime. In Albania the organized crime consists in criminal groups and not in mafia organizations as in many other countries. However Albania has been considered country of origin and transit (mainly toward Italy and Greece) of narcotics. But as long as trafficking of narcotics includes more than one country, then this is an issue not only of Albania to deal with. So, the fight should be in an international level in order to be effective. According the Interior Ministry, Albania since 2014 is not in the list of origin country for cultivating and trafficking narcotics. This paper treats and tries to give some conclusions regarding the actual situation in fighting the cultivation and trafficking of narcotics, and conclusions regarding the obstacles and failures in preventing such crimes, such as involvement of police and other officials, the effectiveness of used methods of investigation and finding the authors. There is a Bureau of International Issues on Narcotics created and assisted by US Department of State, implementation of law, increasing the capacities and effectiveness in criminal proceedings and in trainings of competent bodies and state employees. There has been an enforcement of technology and infrastructure capacities. This paper is based on official records from annual reports of international organizations and bodies. The methods used in this paper are statistical, comparative, and legal method.
\end{abstract}

Keywords: organized crime, economic and politic situation, actual situation, methods of investigation.

\section{Introduction}

The origins of organized crime in Albania have been recorded in the period of change from the totalitarian in the pluralistic system. The transition from a system of total control by the state, with a harsh penal policy, toward fragile democratic system was associated with weak institutions and officials without sufficient education and experience. The situation created in 1997 and the social and financial consequences caused by the collapse of pyramid schemes have been another key moment in the creation of favorable conditions for the development of organized crime in the country. This paper treats the organized crime in Albania, its development and internal structure of criminal groups as well as the features and the factors that encourage organized crime. The focus is on the crimes related to drugs (cannabis sativa, heroin, cocaine, and synthetic drugs) and on forms of trafficking. It is also presented the Albania's role as a source, transit, and consuming country of illicit narcotics. Other treated topics are the measures taken and the effectiveness of the fight against drug-related crimes, as well as recommendations on this issue. There are provided also some statistical data for narcotics trafficking among other crimes that are the fruit of organized crime, given the decisions of the Albanian courts.

\section{Organized Crime}

\subsection{The organized crime in Albania.}

This study treats the phenomenon of organized crime in Albania, in order to recognize and better understand its nature 
and assessing the level of the danger it provides (Elezi, 2002).

In the period 1990-1997, in Albania emerged hierarchical criminal structures in the form of armed gangs, criminal organizations and structured criminal groups. From 2005, criminal networks appear as the most common and appropriate form for the realization of various criminal enterprises. These include various types of trafficking in drugs, arms and ammunition, migrant smuggling and cyber crime. At late 2004-2005, which is the time of the end of the second period of evolution and adaptation of criminal structures, new forms of criminal organizations began to appear. Certain criminal groups, within and abroad, begin to interact actively and continuously in the form of criminal networks, while maintaining the autonomy of the group. Each of these groups and their members assume certain duties and responsibilities without being under control and the obligation to submit to the authority of a particular person.

Given the lack of a final determination of the Albanian organized crime, we can say that Albanian organized crime is divided into two profiles:

1) Organized crime with low criminal profile, and

2) Organized crime with high profile, which has managed not only to establish links with the crime world, but also with the political and economic elite of the country. The Albanian organized crime moves between these two profiles (Zhilla, 2012). Judging from the organization level, organized crime in Albania appears to be increasingly complex and dynamic. ${ }^{1}$

Active criminal groups in Albania are composed of at least 3-4 members and are mostly involved in the trafficking of drugs (mainly cannabis). They also traffic illegal drugs such as heroin and cocaine, toward neighbor countries with destination countries of the European Union (EU).

\subsection{Factors that encourage organized crime.}

Factors that encourage organized crime are political, social and economic factors. These factors and circumstances have led to the creation of the earliest forms of organized illegal activities, as well as the continuous evolution and sophistication to this day. Specifically, these factors are:

- The transition from a totalitarian regime with criminal tough policy toward fragile democratic system with weak institutions, clerks without sufficient education and experience;

- The chaotic situation created in 1997 by the collapse of pyramid schemes and looting of weapon depots;

- Institutions constantly affected by discharges of qualified staff with the change of government;

- Lack of institutional independence and corruption;

- Favorable geographical position between East (countries of production and supply of drugs, like Afghanistan and Turkey) and those in the West (countries of trade and high consumption of these drugs);

- The international character of organized crime and the effects of globalization;

- Lack of political stability in the country for over two decades;

- $\quad$-The weak economy, high levels of unemployment and low income per capita (among the lowest in Europe);

- The disintegration of social structures, which have a negative impact on the family as the nucleus of society;

- Huge and continuous migration of people and importing experiences and criminal connections established abroad;

- Support from the criminal contingent members of the Albanian communities abroad;

- Use of technology and communication tools developed by criminal networks.

\section{Organized Crime and Illegal Narcotics}

The cultivation of the cannabis plant in Albania has begun for the first time in 1992. About 15 cannabis farms were shown for the first time in the south of the country, in villages close to the border with Greece. In 1993 the places with cultivated cannabis were 50 and in 1994 there are hundreds. In the absence of domestic legislation against drug production and trafficking, farmers in Konispol and in the villages of Saranda cultivated cannabis, which then was transported to Greece (Hajdinjak, 2002).

Cannabis has been cultivated almost throughout the territory, especially in certain areas in Shkodra, Tropoja, Kruja, Dibra and Tepelena. Earlier, cannabis was massively cultivated in Lazarat, Vlora River, Mallakastra and Berat.

${ }_{1}^{1}$ The EU Serious and Organised Crime Threat Assessment, https://www.europol.europa.eu/sites/default/files/publications/socta2013.pdf 
More and more are being recruited or used as drug carrier vulnerable persons, unemployed, old people and divorced women. For transportation of drugs, there are used vehicles of international transport companies, bus lines and private vehicles. For drug loading on the vehicles, there are used different ways, such as contracts for fictitious transport, private car purchase, bribery or drivers' threatening.

Cannabis is trafficked mainly to Greece through the green border or hiding in trucks that pass through border points of Kakavija and Kapshtica. There are produced and trafficked different types of marijuana, hashish oil, 'chocolate' and 'skunk', a grafting of the Cannabis Indica with Cannabis Sativa. The above products are used for sale, as well as exchange with hard drugs. Number of users of marijuana in Albania is high. The use of this drug is considered as the first step towards the use of stronger drugs. Albania has reported the presence of synthetic drugs, although not in significant numbers. Despite the lack of domestic market, amounts of amphetamine and ecstasy have entered from Serbia and Bulgaria.

Drug trafficking by Albanian criminal groups has increased significantly since 2008. There are about 528 convicted by the First Instance Court for Serious Crimes, for the period 2008-2013. Only in the first half of 2014, this court had an increase of $13 \%$ of cases trialed for drug trafficking, compared with $2013 .{ }^{2}$

"Criminal groups, have taken leadership roles in the trafficking of cocaine into the EU," the study estimates. "Albania not only serves as an entry point, but also as storage for drugs that are trafficked to the West," it is further stated. ${ }^{3}$

\section{Money Laundering}

Money laundering is closely linked to organized crime, particularly in terms of penetration and influence in economic, political and social situation in the country. The main areas where money is invested are the construction industry, modern processing factories, gambling businesses, mining, fuel, energy production, tourism agencies, as well as the acquisition of various licenses and concessions from the state. Typical ways of introducing criminal proceeds in the legitimate economy are numerous transactions in commercial banks, loans from these institutions, the actions through money transfer agencies, and the use of the identity of family members and relatives. Last year, the value of the seized assets valued at over 10 million. The main concern relates to the low number of seizures, revocation of the confiscation decisions from higher courts and the low number of convictions for this offense. Increasing the power of organized crime through money laundering generates more crime, illegal income, corruption and impunity.

\section{War and Its Efficiency: The Effectiveness of the Fight Against Organized Crime}

Reasons why law enforcement agencies fail in successfully fighting organized crime, are related to poor cooperation and lack of coordination between different agencies of law enforcement, deficient consolidation of institutions that are often subject to political cleansing of experts whenever the government changes, professional level issues, financial problems expressed at low wages and poor logistics, unwillingness, as well as corruption or compromise of some officials (mostly referred to the state police, border police and judicial police, which is located under a double dependency: administrative dependency by police and the procedural dependency by the prosecution). Reasons why Albanian society appears reluctant to denounce organized crime deemed closely related to the lack of confidence in institutions, fear of revenge, corruption, "the sale of the investigative secrecy", the lack of effective protection of witnesses and the lack of a culture of denunciation.

\section{The Measures Taken and the Results of Achievements}

The fight against organized crime, corruption and above all the fight against the cultivation and trafficking of drugs is a priority of the Ministry of Internal Affairs and the Government in general. Cooperation with international partners is a key element in this context that brings good and sustainable in time results. The year 2014 marked the first year when Albania was not the place that served as a source for cultivating and trafficking drugs, a legacy of almost 20 years where Albania was transformed into a garden for the cultivation of narcotics and then trafficking in EU countries. It also means

${ }^{2}$ http://top-channel.tv/lajme/artikull.php?id=279712 61. UNODC, 2013.

${ }^{3}$ http://www.reporter.al/krimi-i-organizuar-po-e-kthen-shqiperi-ne-porte-te-kokaines-per-europen/ 
strengthening the capacity, so it is necessary to still work with partners to increase the professional capacity of the State Police and law enforcement agencies. It also means strengthening the technological capacity and infrastructure of the State Police and law enforcement agencies in the country as a prerequisite for having better results consistently.

Below is represented by a table the place occupied of trafficking of narcotics among other serious crimes that are the subject of organized crime. The trafficking of narcotics takes the major place through other serious crimes (Zhilla, 2015).

\begin{tabular}{|l|c|c|c|c|c|c|}
\hline & $\begin{array}{c}\text { Narcotics } \\
\text { Trafficking }\end{array}$ & $\begin{array}{c}\text { Human } \\
\text { Trafficking }\end{array}$ & $\begin{array}{c}\text { Weaponry } \\
\text { Trafficking }\end{array}$ & $\begin{array}{c}\text { Criminal } \\
\text { Organizations }\end{array}$ & $\begin{array}{c}\text { Immigrants } \\
\text { Smuggling }\end{array}$ & $\begin{array}{c}\text { Illicit } \\
\text { Fines }\end{array}$ \\
\hline Criminal Activity & $42 \%$ & $17 \%$ & $18 \%$ & $6 \%$ & $9 \%$ & $8 \%$ \\
\hline
\end{tabular}

\section{Recommendations}

Recommendations for a more efficient fight against organized crime are:

- The conduction of a comprehensive reform of the institutions that are directly related to the fight against organized crime, including the Judicial Police Service,

- Increasing of cooperation and coordination of actions between the State Police, the National Intelligence Service, the Prosecutor's Office of the General Directorate for Prevention of Money Laundering, the Directorate of Customs and Taxation;

- Developing a professional capacity through different training programs, the guaranteeing of the specialists sustainability, selection of individuals based on merit, moral and social integrity, and without conflict of interest;

- Fighting corruption at all levels of the justice system (the prosecution, the courts and the police);

- Support against organized crime structures in financial terms and providing a social preferential status by law;

- Increasing the number of confiscation of the seized illegal income;

- Establishing the Investigation Directorate that would be responsible for the quality, depth, and the procedural side of the investigation, assessed as very weak by experts;

- $\quad$ Limiting the admission of summary trial for some serious offenses;

- Recruiting the best experts from various fields such as finance, criminology, law, psychology, statistics, information technology, legal medicine, etc into the law implementing bodies,

- Increasing the public awareness of the dangerousness of organized crime, and the role and responsibility of everyone in the fight against it.

\section{Conclusions}

The origins of organized crime in Albania have been recorded in the period of change in the pluralistic totalitarian system. The transition from a system of total control by the state, with a harsh penal policy toward fragile democratic system was associated with weak institutions and officials without sufficient education and experience. In the period 1990-1997, in Albania emerged hierarchical criminal structure in the form of armed gangs, criminal organizations and structured criminal groups. At late 2004-2005 new forms of criminal organizations began to appear. Active criminal groups in Albania are composed of at least 3-4 members and are mostly involved in the trafficking of drugs, mainly cannabis, but also heroin and cocaine, toward neighbor countries with destination countries of the European Union.

The cultivation of the cannabis plant in Albania has begun for the first time in 1992. Drug trafficking by Albanian criminal groups has increased significantly since 2008. There are about 528 convicted by the First Instance Court for Serious Crimes, for the period 2008-2013. Only in the first half of 2014, this court had an increase of $13 \%$ of cases tried for drug trafficking, compared with 2013.

Regarding the factors that encourage organized crime are political, social and economic factors, these are for example the transition from a totalitarian regime toward fragile democratic system with weak institutions, lack of institutional independence and corruption, favorable geographical position between East and West, the weak economy, high levels of unemployment and low income per capita, the disintegration of social structures, which have a negative impact on the family as the nucleus of society, huge and continuous migration of people etc.

Reasons why law enforcement agencies fail in successfully fighting organized crime, are related with poor cooperation and lack of coordination between different agencies of law enforcement, deficient consolidation of institutions that are often subject to political cleansing of experts whenever the government changes, professional level issues, financial problems expressed at low wages and poor logistics, unwillingness, as well as corruption or compromise of 
some officials. The fight against organized crime, corruption and above all the fight against the cultivation and trafficking of drugs is a priority of the Ministry of Internal Affairs and the Government in general. Cooperation with international partners is a key element in this context that brings good and sustainable in time results. The year 2014 marked the first year when Albania was not the place that served as a source for cultivating and trafficking drugs. Although there has been an effective fight the last year (2014 and 2015), it is important to mention that burning the surfaces of cannabis has to be followed with finding the traffickers, sentencing them and confiscating their wealth derived from these crimes. This is the only way of preventing this crime.

\section{References}

Elezi I, "Vështrim mbi zhvillimet e legjislacionit penal shqiptar kundër krimit të organizuar" në "Gjendja e krimit të organizuar në Shqipëri, Kosovë, Mal të Zi, Maqedoni si dhe problemet që lidhen me të" Tirana, October 2002;

The EU Serious and Organised Crime Threat Assessment;

Hajdinjak. M. 'Smuggling in Southeast Europe: The Yugoslav wars and the Development of Regional Criminal Networks in the Balkans'. Center For The Study Of Democracy 2002: 31.

UNODC, 2013:

Zhilla F, Lamallari B, "Vleresimi i riskut te Krimit te Organizuar ne Shqiperi", Fondacioni Shoqeria e Hapur per Shqiperine, Tirana, 2015;

Zhilla F, "Judicial Corruption and Organised Crime: Democratic Transformation and Prospects for Justice in the Western Balkans with case study Albania', PhD not published in King's College London, December, 2012;

http://top-channel.tv/lajme/artikull.php?id=279712

http://www.reporter.al/krimi-i-organizuar-po-e-kthen-shqiperi-ne-porte-te-kokaines-per-europen/

https://www.europol.europa.eu/sites/default/files/publications/socta2013.pdf 